\title{
TRACTOR SERVICES CHALLENGES AND CURRENT DEMAND TRENDS BY SMALLHOLDER FARMERS IN NIGERIA
}

\author{
Achoja Roland Onomu ${ }^{1 \bowtie}$, Michael Aliber ${ }^{1}$, Ikechi Kelechi Agbugba ${ }^{2}$ \\ ${ }^{1}$ University of Fort Hare, South Africa \\ ${ }^{2}$ Rivers State University, Nigeria
}

\begin{abstract}
Many smallholder farmers, particularly those in developing countries do not practice mechanisation such as the use of tractor due to some plethora of issues among which include: lack of demand, problematic supply model and failed mechanisation programmes. Based on the problems associated with smallholder mechanisation and the roles lack of demand played in past mechanisation programmes, this research investigated the characteristics and the challenges of tractor service providers, as well as the analyses of the current demand trends by the sampled smallholder farmers for tractor services, while forecasting the future demand in Delta and Benue States of Nigeria. The study employed a snowball sampling technique to collect field survey data from 20 private tractor service providers (SMEs) and 6 government tractor service providers in four local government areas of Delta and Benue States. Descriptive statistics, weighted mean score and trend analyses were used to interpret the result. The study finds that tractor services provide employment for rural dweller, particularly male; use less of household labour and the majority of those involved own only a tractor. Among the different challenges such as the inability of smallholders to pay a high price, long distance to get mechanic, and the high cost of maintenance/high cost of the spare part; too few qualified tractor mechanics is ranked the most severe challenge. While both SMEs and government tractor service providers face some common challenges, poor maintenance and corruption predominates government tractor services. There has been a constant increase in the demand for tractor services by the smallholder farmers from 2013 to 2016 and the demand is forecast to continue. Based on the different challenges associated with the provision of tractor services to the smallholder,
\end{abstract}

it was suggested that the government should support market driver tractor service provision.

Keywords: characteristics, government, hire, private, prospect

\section{INTRODUCTION}

For more than a decade now, labour-saving technologies have seen an unprecedented level of adaptation, however; its intensification and sustainability has created a bottleneck; most especially in developing countries and among smallholder farmers (Pingali, 2007). Many smallholders farmers still plant seeds by hand, weed by hand, and harvest by hand, indicating limited supply of improves farm power (Maragelo, 2008).

Farming activities are valued by the by either of the labour supply such as the human, animal or mechanical power. The used of these various farm power systems have been identified as a significant factor which distinguishes farmers and as a basis for the analysis of farmer's livelihood (Sims and Kienzle, 2006). Human and animal powers are the significant sources of farm labour supply among rural household, and the sole use of human labour by most smallholders farmers are identified as poverty stimulant and cause of poor their performance in the farm business (Pingali, 2007). Animal labour plays an essential role in substituting for

$\bowtie$ Achoja Roland Onomu, Department of Agricultural Economics \& Extension, University of Fort Hare, Private Bag X1314, Alice, South Africa, e-mail: roland.onomu@gmail.com; https://orcid.org/0000-0002-7329-5781 
mechanical power by a majority of smallholders; however, the supply of draught animal is constantly decimated (Simalenga et al., 1999). According to Abubakar and Ahmad (2010), farmers who were using animal traction are in search of alternative farm labour due to the challenge such as the impact of theft, sales, disease and pest such as the tsetse fly-free.

The supply of mechanical power has been recommended as a sure way of finding a solution to problematic farm power challenges, however, the supply of mechanical power is limited by many factors including limited investment in mechanization. Moreover; smallholders do not have the capacity to own their personal tractor, resulting in low use of tractor services among smallholders (IFC, 2013; Challa, 2014). The suppliers of tractor services power to the smallholder farmers are basically group into government and private tractor service providers. In Nigeria for example, the government dominates the supply of tractor services to the farmers (The Nations, 2015). Mijinyawa and Kisaiku (2006) and Takeshima et al. (2013) reported that much of the tractor service in Nigeria is supplied or operated by the government via either direct sales, subsidisation or direct tractor hiring service. Nevertheless, private owner tractor operators are emerging. Moreso, cooperatives have also been recognised as a supplier of tractor services to the smallholder farmers (Kamboj et al., 2012).

The constraints such as high costs of tilling or harvesting and the general operation of tractor service together with the government failed mechanization programme are the primary reasons that reduced the demand for tractor services among smallholders (BishopSambrook, 2005; Bowman and Zilberman, 2013). The lack of demand for mechanisation by most farmers in Africa was a contributed factor to the lack of investment in mechanisation (Diao et al., 2014).

The study fills the gap in the literature by investigating the current trend of demand for tractor services by the smallholder farmers while forecasting the demand for tractor services by smallholder farmers in the next four years. The nature and the characteristics of SMEs and government tractor were also investigated. More so, this study did not only identify the challenges faced by the tractor service but also filled the gap in the existing literature by investigating the most severe challenges confronting the tractor service providers.

\section{LITERATURE REVIEW}

\section{Description of SMEs and SMEs tractor}

Economy Watch EW (2010) observed that there is no single definition of SMEs mainly because of the wide diversity of SMEs businesses. However, EW stated that one of the best criteria to describe SMEs should is based on the maximum number of employees, maximum turnover and maximum annual balance sheet total (Economy Watch EW, 2010). Takeshima et al. (2013) defined SMEs concerning farm mechanisation as a condition where small-scale tractor service providers or cooperative who own one or two tractors render tractor services to smallholder farmer in an area to make a profit. Of late, SMEs hire tractor rental services have acted as a catalyst that revolutionised the mechanisation of the agricultural sector of some countries to the extent that some researchers are currently advocating for tractor hire service as the best model for mechanisation (Singha et al., 2012).

Small and Medium Micro-enterprise has been widely regarded as the driving force in economic growth and job creation in both developing and developed countries (Norman, 2012).

However, the survival rate of small, medium and micro-enterprise is relatively low; as only less than half of the newly established businesses have been able to survive beyond a period of five years (Brink et al., 2003). Like other businesses, most SMEs tractor service providers are soaked up with different challenges that tend to inhibit their effectiveness, growth, and increased their cost of service. One of the challenges is the inability of the smallholder farmer to pay a premium price. There is natural ceiling beyond which smallholders find it difficult or unwilling to hire tractor for ploughing, harvesting, tilling ridging, transporting and every other tractor service activities which makes it difficult for most smallholders to use private tractor services effectively (Bishop-Sambrook, 2005; Takeshima et al., 2015; Takele and Selassie, 2018).

\section{METHODOLOGY}

The study areas were Delta and Benue States, Nigeria. Each of the states is located in the Southern and Northern part of Nigeria respectively. The decision to purposefully select one state from the Northern and another state from Southern Nigeria is because Nigeria is divided into Northern and Southern Nigeria. Hence, selecting one state each from either part of Nigeria will allow for 
comparison in terms the current pattern of the use of tractor services among the smallholder farmers in each region and the availability of tractor service providers in the two regions. In each of the states, the local government areas where agriculture is not the dominant activity were also purposefully excluded from the study. Although the purposive sample design is a non-probability sample type which is noted to be biased, the choice of purposive sampling design is based on the fact that some of the Local Government Areas (LGA) do not involve much in agricultural activities. Four Local Government Areas which are Oshimili-North, Ethiope-East, Agatu and Konshisha were randomly from the agricultural dominant local government.

\section{Sampling design and sample size}

Two separate semi-struction questionnaires alongside with interview were used to collect data from the respondents. One was for the government/cooperative and the other for the private tractor service providers. However, there were no cooperative tractor service in the study areas. The reason for using separate questionnaires for government and private tractor service providers was to ensure that the variations in the two tractor service providers are captured. Information on tractor service providers were collected from the Agricultural Development Programme (ADP) in Delta State and Department of Government Hire Tractor Service in the Delta State Ministry of Agriculture (DSMOA) in Benue State. The Assistant Chief Agriculture Officer (ACAO) of the (SMOA) at the local government level assisted in locating some of the tractor service providers. The ACAO is the head of the state department of agriculture in each local government. Tractor service providers were sampled using a snowball sampling type. The decision to use snowball sampling was based on the fact that the number of persons involved in tractor services is relatively low and in most cases, they easily know themselves. An effort was made to cover eventually all the tractor service providers in each local government. Twenty private tractor service providers referred to as SMEs in this study and six government tractor service providers were sampled using the snowball. Effort was to ensure that almost all the tractor service provider in each local government was covered. This was done by thoroughly investigating if there is any tractor service provider that has not been sampled. The six government tractor services sampled were the only government functioning registered tractor services as when the data were collected. There were twenty two tractor service providers operating as SME in the study areas when the data were collected. However, only twenty SME tractor service providers be sampled. The other two could not be researched.

\section{Variable and data analyses}

The number of tractors own (actual), household member involvement (actual), number of people employed (actual), the number of permanent staff employed (actual), involvement in other occupations (yes/no) and other types of occupation (specify) were some of the questions peculiar to the private tractor service provider questionnaire. In the case of government tractor services, they were just simply asked the numbers of people that assist the driver in the field for a particular work. Age of the respondents (actual age), education status (level of education), tractor service experience (years involved), and the number of smallholder farmers work for (actual) are were collected from both government and private tractor services and the data were also measured and analysed using descriptive statistics such as frequency, percentage and mean. The challenges of the tractor service providers were ranked in order of severity as it is peculiar to the individual tractor service provider. The severity of the challenges was analysed weighted score grade. Trend analyses were used to investigate and forecast the trend and the demand for tractor services by the smallholder farmers household head from 2013 to 2016. The forecast was done using year 2013-2016 because only one tractor service provider had a record beyond 2013. That is, the majority of the tractor service providers could not provide record beyond 2013. Hence, our prediction is based on the available data. Most importantly, our model followed the step of Parsons (2020) who stated that business turnover of two circles could enable "bottom-up" prediction of small business.

\section{RESULTS}

\section{Demographic characteristics of the respondents}

The socio-demographic characteristics of the respondents discussed included: age, gender, marital status, educational status, years of experience in tractor services, number of persons employed, number of tractors own and involvement in other type occupations and sources of finance. The socioeconomic characteristics discussed are presented in Table 1 and in Table 2. 
Onomu, A. R., Aliber, M., Agbugba, I. K. (2020). Tractor services challenges and current demand trends by smallholder farmers in Nigeria. J. Agribus. Rural Dev., 4(58), 379-391. http://dx.doi.org/10.17306/J.JARD.2020.01288

Table 1. Mean description of the SME socio-economic characteristics

\begin{tabular}{|c|c|c|c|c|c|}
\hline \multirow{2}{*}{ Variable } & \multicolumn{2}{|c|}{ Proportion of activity } & \multirow[b]{2}{*}{ Min } & \multirow[b]{2}{*}{ Max } & \multirow[b]{2}{*}{ Mean } \\
\hline & Frequency & Percentage & & & \\
\hline \multicolumn{6}{|l|}{ Age (in years) } \\
\hline$\leq 30$ & 0 & 0.0 & \multirow{7}{*}{35} & \multirow{7}{*}{66} & \multirow{7}{*}{52} \\
\hline $31-40$ & 3 & 15.0 & & & \\
\hline $41-50$ & 6 & 30.0 & & & \\
\hline $51-60$ & 7 & 35.0 & & & \\
\hline $61-70$ & 4 & 20.0 & & & \\
\hline 71 and above & 0 & 0.0 & & & \\
\hline Total & 20 & 100.0 & & & \\
\hline \multicolumn{6}{|l|}{ Education status } \\
\hline Informal education & 0 & 0.0 & \multirow{5}{*}{6} & \multirow{5}{*}{18} & \multirow{5}{*}{12} \\
\hline Primary education & 1 & 5.0 & & & \\
\hline Secondary & 12 & 60.0 & & & \\
\hline Tertiary education & 7 & 35.0 & & & \\
\hline Total & 20 & 100.0 & & & \\
\hline \multicolumn{6}{|l|}{ Years of experience } \\
\hline$\leq 5$ & 10 & 50.0 & \multirow{4}{*}{1} & \multirow{4}{*}{16} & \multirow{4}{*}{6} \\
\hline $6-10$ & 8 & 40.0 & & & \\
\hline 11 years and above & 2 & 10.0 & & & \\
\hline Total & 20 & 100 & & & \\
\hline \multicolumn{6}{|l|}{ Household employed/assist as labour } \\
\hline Do not use household member & 12 & 60.0 & \multirow{5}{*}{0} & \multirow{5}{*}{2} & \multirow{5}{*}{1} \\
\hline Use only one household member & 5 & 25.0 & & & \\
\hline Use Tw household members & 3 & 15.0 & & & \\
\hline Use three and more household members & 0 & 0.0 & & & \\
\hline Total & 20 & 100 & & & \\
\hline \multicolumn{6}{|l|}{ Number of people employed as staff } \\
\hline 1 & 2 & 10.0 & \multirow{4}{*}{1} & \multirow{4}{*}{3} & \multirow{4}{*}{2} \\
\hline 2 & 11 & 55.0 & & & \\
\hline 3 & 7 & 35.0 & & & \\
\hline Total & 20 & 100 & & & \\
\hline Number of permanent staffs employed & & & & & \\
\hline No permanent staff & 5 & 25.0 & & & \\
\hline One permanent staff & 11 & 55.0 & & & \\
\hline Two permanent staff & 4 & 20.0 & 0 & 2 & 1 \\
\hline Three permanent staff and above & 0 & 0.0 & & & \\
\hline Total & 20 & 100 & & & \\
\hline Number of tractors owned & & & & & \\
\hline 1 & 17 & 85.0 & & & \\
\hline 2 & 3 & 15.0 & 1 & 2 & 1 \\
\hline 3 and above & 0 & 0.0 & 1 & 2 & 1 \\
\hline Total & 20 & 100 & & & \\
\hline
\end{tabular}

Source: field survey data. 


\section{Age}

Looking at the age distribution of the respondents as shown in Table 1; it is observed that there is no wide variation in the age distribution of those involved in the business of SME tractor services. However, Table 1 reveals that the age group of 51-60 years old has the highest percentage of people that are involved in the SME tractor service business. This is followed by respondents in the age bracket of $41-50$ years old. The average age of the tractor service providers in the study is 52 years. This result implies that people who involve in the tractor services business are in their prime/middle age. This result is consistent with the research findings of BishopSambrook (2005) and Agbugba et al. (2008).

\section{Educational status}

From the Table 1, all SME tractor service providers have formal education, with a high number (60 percent) of the respondents having secondary education and the mean total years spent in school by all the respondents is 12 years. The formal education achieved by SME tractor service providers helps their tractor service business.

\section{Number of years of experience}

The years of experience show the duration the individual has been involved in such activity, business or occupation. The experience gained by tractor operator is fundamental to the successful operation of tractor services. Nevertheless, the field survey reveals the maximum years of experience of the tractor service providers in the study areas to be 16 years, with only 10 percent of the respondents having years of experience that cumulates to 11 years and above. In other words, the result of the years of experience exposes that most of the tractors in the study areas are relatively new.

\section{Household employed/assist as labour and other people employed as staff in tractor services}

Inferring from Table 1, results indicated that the majority (60 percent) of the tractor service providers do not engage the use of household members as labour. However, 25 percent of the SME tractor service providers engage at least a household member that assist in the business of tractor services. Only 15 percent of the SME tractor service providers employed two or more household member. As shown in Table 1, the maximum number of people employed by the SME tractor service providers in the study area is 3 . The result expresses that the business of tractor services does not require a large number of people to start.

The respondents were further asked to respond to the question stating the number of people other than their household member employed in their business. As shown in Table 1, the maximum number of people employed by the SME tractor service providers in the study area is 3 . The result expresses that the business of tractor services does not require a large number of people to start. However, the result indicates that SME tractor services business employs at least one person, with 55 percent of the respondents employing two people (either permanent or casual staffs) to assist them in tractor business operation.

Among the staff employed, Table 1 shows that the bulk (55 percent) of the respondents have one permanent staff, who is mainly the driver, while only 20 percent of the SME tractor service providers have two permanent staff and 25 percent do not have a permanent staff.

\section{Number of tractors owned by the SME respondents}

Despite the need for a reasonable increase in the amount of tractor available to the smallholder farmers through SME, none of the SME respondents has more than two tractors The result shows that the majority of the SME tractor service providers lack adequate tractors to do well in the business operation. Table 1 equally explains that the huge proportion ( 85 percent) of the respondents has just one tractor.

\section{Gender}

The gender results establish that majority of the respondents $(90 \%)$ that engage in tractor services business in the study areas are male, while only $(10 \%)$ percent are females. This finding agrees with the findings of Naushad et al. (2009) in Pakistan, which reported that the majority of those involved in SME tractor services are mainly males. This result could be attributed to the fact the business of SME tractor service is rigorous which demands strength.

\section{Marital status}

The result of the SME tractor service providers indicates that no unmarried single household is involved in the business of tractor services. On the contrary, the majority $(75 \%)$ of the respondents who involve in hire tractor services are married (see Table 2). This could be due to 
Table 2. Distribution of the SMEs according to their demographic characteristics

\begin{tabular}{|c|c|c|}
\hline Tractor service providers & Frequency & Percentage \\
\hline \multicolumn{3}{|l|}{ Gender } \\
\hline Male & 18 & 90.0 \\
\hline Female & 2 & 10.0 \\
\hline \multicolumn{3}{|l|}{ Marital status } \\
\hline Single & 1 & 5.0 \\
\hline Married & 15 & 75.0 \\
\hline Divorced & 2 & 10.0 \\
\hline Widow / widower & 2 & 10.0 \\
\hline \multicolumn{3}{|l|}{ Other occupations } \\
\hline Yes & 17 & 85.0 \\
\hline No & 3 & 15.0 \\
\hline \multicolumn{3}{|l|}{ Types of occupation } \\
\hline Farming & 3 & 15.0 \\
\hline Trading & 4 & 20.0 \\
\hline Artisan & 1 & 5.0 \\
\hline Wage earner & 6 & 30.0 \\
\hline Retired staff & 3 & 15.0 \\
\hline Did not disclose other occupation & 3 & 15.0 \\
\hline \multicolumn{3}{|l|}{ Sources of finance } \\
\hline Government assistance & 9 & 45.0 \\
\hline Loan from friends/family & 1 & 5.0 \\
\hline Loan from commercial bank & 1 & 5.0 \\
\hline Personal saves & 3 & 15.0 \\
\hline Cooperative & 4 & 20.0 \\
\hline Did not disclose sources of finance & 2 & 10.0 \\
\hline \multicolumn{3}{|l|}{ Tractor service provider in a LGA } \\
\hline Ethiope East & 3 & 15.0 \\
\hline Agatu & 6 & 30.0 \\
\hline Konshisha & 8 & 40.0 \\
\hline Oshimil North & 3 & 15.0 \\
\hline
\end{tabular}

Source: field survey data.

the fact that, like other SME businesses being married is one of the social capitals that encourages starting up of the business.

\section{Tractor-service provider involvement in other occupations}

Like some other business owners that have different businesses, some of the SME tractor service providers have other occupations from which they generate income to augment the income from tractor services. Majority $(85 \%)$ of the respondents indicate that they have another form of occupation from which they generate income (see Table 2). Therefore, the study shows that most tractor service providers have additional sources of income. This result is in concordance with the finding of Issa (2018) which reported that tractor service provider involved in other engage in off-farm supplementary business activities such as trading, artisan, construction and government employment. Identifying the other types of occupation from which the SME tractor service respondents generate income, Table 2 shows that $30 \%$ of the respondents being the highest are wage earners, particularly from the government sector.

\section{The sources of finance for the purchase of tractor by the SME service provider}

There are various sources of finance from which the SME tractor service providers raised funds to finance the purchase of their tractors. However, as appears in Table 2, the government remains the ultimate financier of the tractors or the major source of finance through which the SME tractor service providers get money for the purchase of their tractor. This result disagrees with the findings of Takeshima et al. (2015) that the most $(82 \%)$ of the SME tractor service providers finance the purchase of their tractors with their own personal savings. However, the result concurs with the findings of Amadhila (2016) which ascertained that the government of Namibia is the major financier and operator of tractor services.

\section{The distribution of SME tractor service providers}

Table 2 establishes that the two local governments from the Benue State (Konshisha and Agatu) have the highest amount of SME tractor service providers. This is an indication that more investment is made into agricultural machinery in the Northern part of Nigeria (Benue State) compared to the Southern part of Nigeria (Delta State). 


\section{Demand trend for tractor services by smallholders}

The trend of demand for tractor services by the smallholder farmers from year 2013-2016 is presented in Fig. 1. It was calculated and forecasted from the total sum of the smallholder farmers each tractor service provider got at the end of each year. Hence, the number of smallholder farmers who used tractor at the end of each year was calculated by dividing their sum with the total number of the tractor service provider that operated in that year. That is, the sum of all the smallholder farmers who used tractor in a particular year were divided by both all the private and government tractor service providers who operated in that year. This is to show if there were general changes in the demand trend among the smallholder farmers over the evaluated years (2013-2016). More so, this is to ensure that the same growth trend will be experienced by any person who decides to go into the business of tractor services in the study areas.

From the results, the trend of demand for tractor services by the smallholders for four consecutive years (2013-2016) is on constant increase as indicated in Fig. 1. The results further depicts that year, 2013 records the lowest numbers of client that demanded the tractor-service providers. In 2013, the average number of smallholder farmers that demanded the services of the tractor service providers was 102 persons. In 2014, the tractor service providers experienced an average increase in the number of smallholders who used tractor services for their farm from 102 to 113 persons. By the end of November 2016, the average numbers of farmers the tractor service provider got have increased to 138 people. This shows that there was growth in the demand for tractor services in the study area. This suggests that there is a good market prospect for tractor service providers in terms of having more smallholder farmers engaging the services of tractor service providers if the trend in Fig. 1 is sustained. These results validate the findings of Amadi et al. (2013) that in Nigeria, there is a progressive increased in the numbers of smallholder farmers who used the tractor in 2006 from $22 \%$ to $42 \%$ in 2009.

By forecasting with all things being equal, Fig. 1 signals that the by the end of 2020, the numbers of smallholder farmers the tractor service provider is expected to have would have increased to 188 people. The increase in the number of smallholders using tractor could be associated with the awareness in the use of a tractor and the developmental strive made by the government through a programme such as agricultural inputs e-wallet and the transformation programme that encouraged more people particularly the youth to go into agriculture.

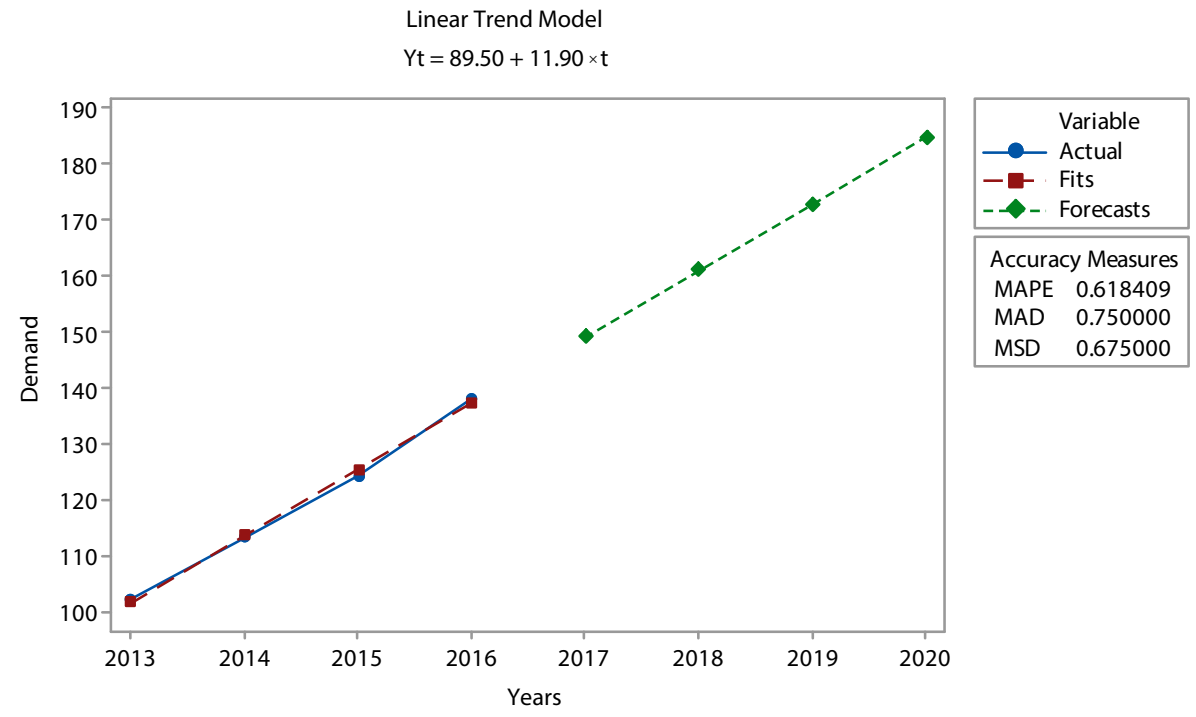

Fig. 1. Total clients the SME providers have in the end of each year (2013-2016) with a forecast

Source: field survey data. 


\section{Challenges faced by the SME tractor service providers}

The service providers were asked to rank their various challenges based on the severity of the challenge as it is peculiar to them as an individual. Fourteen challenges were identified to impede the growth of tractor services in the study areas. The mean weighted scores were calculated for each of the challenges based on the frequency of the challenge and the position under which the challenge appeared as listed by the SME tractor service provider. The mean weighted score challenges were determined in order to rank the severity of each of the challenges facing the SME tractor service providers. Some of the challenges identified by the tractor service providers were nature, while some others were caused by other people. For example, while seasonality is a natural occurrence that affects tractor service provider, the sales of inferior spare parts are man-made.

\section{Too few qualified Tractor Mechanics}

In Table 3, too few qualified tractor mechanics appears thirteen times within the listed challenges faced by the SME tractor service providers in the study area. Although the too few qualified tractor mechanics is not the most frequent challenge identified by the SME tractor service providers, it is ranked as the most severe $\left(1^{\text {st }}\right)$ challenge obstructing the growth of the SME tractor services. This is an indication that tractor repair personnel are few in the study areas. This result concurs with the findings of Sims et al. (2011) that tractor repair personnels and tractor service repair centers are scarcely available, particularly in less developed countries. This result is also consistent with the findings of Challa (2014) in Ethiopia.

\section{Challenge of Inferior Spare Parts}

From Table 3, results indicated that the ranks the grimness of inferior spare to be a 5 th most intense challenge, with a mean weighted score of 33 . Some of the

Table 3. Challenges faced by SME tractor service providers

\begin{tabular}{|c|c|c|c|c|c|c|}
\hline Challenges & $\begin{array}{l}\text { How frequent } \\
\text { it was listed }\end{array}$ & $\begin{array}{c}\% \text { of } \\
\text { frequency }\end{array}$ & $\begin{array}{l}\text { Weighted } \\
\text { score }\end{array}$ & $\begin{array}{l}\text { Mean weighted } \\
\text { score }\end{array}$ & $\begin{array}{c}\% \text { of weighted } \\
\text { mean }\end{array}$ & Rank \\
\hline Distance to place of repair & 16 & 15.1 & 380 & 47.5 & 13 & 3 th \\
\hline Too few qualified tractor mechanics & 13 & 12.3 & 475 & 59.4 & 16 & $1 \mathrm{st}$ \\
\hline Seasonality & 8 & 7.5 & 190 & 23.8 & 6 & 7 th \\
\hline Inability of smallholders to pay a high price & 15 & 14.2 & 445 & 55.6 & 15 & 2nd \\
\hline Limited access to market & 2 & 1.9 & 25 & 3.1 & 1 & 14th \\
\hline Lack of access to finance & 5 & 4.7 & 120 & 15.0 & 4 & 9th \\
\hline The high price of diesel & 5 & 4.7 & 145 & 18.1 & 5 & 8th \\
\hline Inferior spare part & 8 & 7.5 & 265 & 33.1 & 9 & 5 th \\
\hline Stumps & 8 & 7.5 & 230 & 28.8 & 8 & 6th \\
\hline Small nature of the smallholders farm & 11 & 10 & 315 & 39.4 & 11 & 4th \\
\hline $\begin{array}{l}\text { High cost of maintenance and high cost of } \\
\text { spare part }\end{array}$ & 3 & 2.8 & 100 & 12.5 & 3 & 10 th \\
\hline Lack of trained tractor drivers & 3 & 2.8 & 75 & 9.3 & 2 & 11 th \\
\hline Lack of government support & 6 & 5.7 & 145 & 18.1 & 5 & 8th \\
\hline The high price of new tractor & 2 & 1.9 & 45 & 5.6 & 1 & 12 th \\
\hline Lack of managerial and operational training & 1 & 0.9 & 35 & 4.4 & 1 & 13th \\
\hline Total & 106 & 100 & 2990 & 373.7 & 100 & 0 \\
\hline
\end{tabular}

Source: computed from field survey data. 
SME tractor service providers said that the challenge of inferior spare parts is so terrible that they sometimes prefer to purchase a used spare part gotten from a scrap tractor imported from developed countries in replacement of the spoil parts. This result agrees with the findings of Maradun et al. (2013) who noted that the provision of original spare parts is not only underdeveloped and scarce; its prices are ridiculously high if it is mistakenly gotten. They also complained that the use of inferior spare parts, together with the inefficiency of some of the technicians forced them to be doing maintenance frequently, especially the fixing of the tractor spindle.

\section{Inability of smallholders to pay a high price} The inability of the smallholder to pay the desired price and the high level of indebtedness by some of the smallholder farmers has the second highest percentage (15) of the mean weighted score. This places the inability of the smallholder farmers to pay the desired price as the second most severe challenge hampering the development of SME tractor services in the study areas. This is because the tractor service providers still want smallholder farmers to pay higher prices than the minimum price (N 20,000 and N18,900) charged for ploughing in Delta and Benue states respectively.

\section{High cost of maintenance}

The cost of tractor maintenance is another challenge mentioned by the SME tractor service providers. The cost of maintenance is so high that the minimum amount of money spends by SME tractor service providers on routine maintenance in the study areas is N19,000. The high cost of maintenance is ranked $10^{\text {th }}$ most painful challenges encountering by the SME tractor service providers. This result is consistent with von Hase (2013) who identified the high running costs of staffs and tractor maintenance to play a key role among the challenges faced by private tractor service providers.

\section{Challenge of long-distance travelled for repair}

In Table 3, the challenge of the distance travelled to the place of repair, or distance travelled by the repair person was mentioned sixteen times by sixteen tractor service providers. This makes the challenge of the distance travelled to get a technician to have the highest frequency of occurrence among the other challenges facing by SME tractor service providers in the study areas. In other words, the majority $(15 \%)$ of the respondents mentions long-distance travel for the repair of a tractor or to get a technician as a key challenge facing them. Some of the respondents both in Delta and Benue States reported that in some occasions, they have to travel to the neighbouring states to get technicians to repair their tractor. The problem of long-distance travel to get repairers is a common challenge in many states of Nigeria. Hence, this result agrees with the findings of Maradun et al. (2013) who noted that due to scarcity of tractor repair personnel in Zamfara State, Nigeria, tractor owners had to travel long distance to get repairers, and there is no single tractor repairer's workshop in Zamfara State that has full equipment needed for the repair of tractors.

\section{Fragmentation of the smallholder farms}

The small size of smallholders' plots was equally named as another challenge faced by tractor service providers in the study areas. The challenge of the small nature of the smallholder farmers has a weighted score of 315 and it is ranked the fourth most serious challenge limiting the growth of SME tractor services in the study areas. The tractor service providers reported in an interview during the time of the data collection that many of the smallholders in the study have fragmented farms which make it difficult to use the tractor on. This result supports the observation of Sims et al. (2016a) that the small and fragmented nature of smallholder fields is problematic to tractorisation and tractor owners.

\section{Impact of too many stumps in the smallholder farm}

The presence of the stump is sixth most severe challenge confronting the activities of the SME tractor service providers. The presence of stumps disturbs the free movement of the tractor, it destroys the blade of the disc harrow and it slows down the speed of operation. Some of the SME tractor service providers said that in some fields, they have to employ the services of additional casual workers that assist in the removal of stumps. The increase in the numbers of casual workers consequently results to rise in the expenditure. The SME service providers equally said in some conditions, they have to inspect the field to be ploughed to ascertain the level of presence of the stump before they make their charges. 


\section{Challenge of season}

While seasonality does not have a direct impact on the tractor, neither does it cause by human activities, it drastically impacts the income of the SME tractor service providers during offseason. The numbers of smallholders that demand the services of SME tractor service providers extremely reduced in some seasons. In Table 3, seasonality ranks seventh most treating challenges in the development of SME tractor services. This result is consistent with Sims et al. (2011) that mechanisation hire services demand is time-bound due to the seasonality of agricultural activities.

\section{Lack of government support}

Lack of government support is also a challenge to the SME tractor service providers. Lack of government support has a mean weighted score challenge of 145 , and it is ranked eighth most severe challenge among the challenges faced by the SME tractor service providers as shown in Table 3. When asked to list how the government is supporting the growth of SME tractor services, all of the respondents said they do not receive any support from the government. However, some of the SME service providers agreed that the only support they have received from the government was the gift of the tractor. Those who received tractor from the government acknowledge the fact that they went into the business of tractor service after they had received their tractor from the government.

\section{High price of diesel}

The constant rise in the price of the diesel makes the tractor service providers to increase the price of their services which in turn prevents the majority of the smallholder farmers from affording the price. This result supports the argument of Sims et al. (2016b) that high and constant rise in fuel price is a major concern for the tractorisation of the smallholder farmers.

\section{Lack of access to finance}

The role of finance is very significant in any business development. The growth and expansion of any business are likely impossible without access to finance. Hence, the lack of access to finance has been identified as a major pitfall for the development of SME tractor hiring business by the respondents. As recognized by the SME tractor service providers, lack of access to finance rank ninth most awful challenge that affects the SME tractor service provider in the study area (see Table 3). The result concurs with Zhou (2016) who reported that one of the severe challenges impeding the flourishing of mechanisation in many African countries is lack of access to credit. The SME tractor service providers said that, despite the fact that they already own tractor, they cannot work to the bank, especially commercial banks to request for a loan for the expansion of their business. They stated further that commercial banks turn down their loan request irrespective of the fact that they put in their tractor documents. A similar report by Sims et al. (2016a) noted that the lack of desire by commercial banks in granting loans for agricultural activities is a submerging cause why the development of the smallholder mechanisation is stunted.

\section{High price of tractors}

The challenge of lack of access to finance together with the high price of a new tractor form the reason the majority of them do not own more than a single tractor. Some of the SME tractor service providers said they would have purchased a new tractor if they have access to finance. In spite of the reality that the SME tractor service providers do not have access to finance, they said that the high price of a new tractor has contributed to their predicament.

\section{Limited access to the premium market (smallholders)}

As indicated in Table 3, the challenge of limited access to the premium market (smallholder farmer) is second to the least challenges faced by the SME tractor service provider in the study areas with only 1.9 percent level of occurrence in the ranking. Considering limited access to the smallholders as a challenge by the SME tractor service providers could be attributed to the inability of some of the smallholders to pay a high price for the services of SME tractor service providers.

\section{Lack of training}

From Table 3, results showed that lack of managerial and operational training is ranked the least challenge facing the SME tractor service providers in the study areas. This result agrees with Sims et al. (2011) that hire service providers to need training in the areas of equipment maintenance and operation. 


\section{Lack of skilled tractor operators}

The challenges of lack of trained tractor operators/drivers could be attributed to the fact that many people do not grow up choosing the operation of the tractor as a career. This result agrees with the findings of Daum and Birner (2017) that all the stakeholders involved in the promotion of mechanisation services for the smallholder farmers in Ghana encountered the problem of limited train tractor operators.

\section{Government-owned tractor hire services}

All of the government tractor service providers interviewed in both Delta and Benue States are males and have formal education. The highest level of education acquired by the respondents in charge of the government tractor hiring service sampled were BSc (honours).

\section{Lack of tractors in both states}

When asked if there are enough tractors in the local government areas, all of the government tractor service providers like the SME tractor service providers said there are not enough tractors in their local government. This is an indication that more tractors are needed in both states.

\section{Challenges faced by the government tractor service providers}

When asked to list the challenges they encounter, the government tractor service providers listed the challenges to include; lack of funds/finance location for the maintenance of the tractor, lack of supervising vehicle, the small nature of smallholder farmers, and long-distance travel for operation, Lack of manpower/staff capacity and corruption particularly from the operators. Like the SME tractor service providers, the government tractor service providers also identified the small nature of the smallholder field as another major challenge that is weakening the efficiency.

\section{CONCLUSION}

This study is motivated by the poor tractorisation transformation in Nigeria, and to holistically unveil all challenges inhibiting its transformation while investigating the current demand trend. There is lack of empirical research that investigates the characteristics of the supplier of mechanization services such as tractor service providers, the challenges the prevent its sustainability, the current demand trend for tractor services by the smallholder farmers and the possible nature of the future demand.The study revealed that the majority of those involved in the business of providing tractor services only have secondary education. This means that high level of education is not required to start the business of tractor services. The businesses of tractor services do not need many people to start-up. Reasonable numbers of those involved in it employs one permanent staff. More so, the study showed that there is prospect for the growth of hire tractor services due to the high demand for it by the smallholder farmers and such, hire tractor services should be encouraged and the challenges associated with tractor services should be addressed, especially the most severe challenges among the SME tractor service provider. Among the challenges of SME tractor service providers, too few qualified tractor mechanics, the inability of smallholders to pay a premium price and long distance to place of repair are the most severe challenges. The small nature of the smallholder farm is a challenge to both the SME and government tractor services. However, the challenges of poor maintenance and corruption are peculiar to government tractor services.

\section{RECOMMENDATIONS}

Based on the findings of the study and the significance of tractor services in providing job opportunities for rural households, the following recommendations were made:

- Government should establish tractor repair and operational training centre in each local government. Since there are elements of poor maintenance and corruption that are peculiar to the government operated tractor service, an alternative policy of private market-driven tractor services where the government creates a conducive atmosphere for the private entrepreneur to strive should be formulated rather than direct involvement in the rendering of tractor services.

- Moreso, since there is an increasing demand for tractor services, it is therefore suggested that people should invest in the business of tractor services.

\section{Suggestions for further study}

More research should be done on the contribution of tractor service sources to the smallholder efficiency. This will better guide the government and policy makers 
on which tractor sources to strengthened. Further research should also be done to determine the profitability of tractor services. Further research is also suggested to investigate the willingness of the smallholder farmers to pay a premium price for tractor services.

\section{SOURCE OF FINANCE}

Agricultural and Rural Development Research Institution ARDRI of South Africa.

\section{ACKNOWLEDGEMENTS}

Our appreciation goes to Agricultural and Rural Development Research Institution ARDRI of South Africa for financial support. We also sincerely appreciate the general manager and staff of government tractor hire services in the Ministry of Benue State Agriculture (2017 staff) as well as the chief engineer and staff of Delta State Tractor Hiring Service at the Agricultural Development Programme (2017 staff) for their responses and support during the data collection.

\section{REFERENCES}

Abubakar, M.S., Ahmad, D. (2010). Utilization of and Constraints on Animal Traction in Jigawa State, Nigeria. Austr. J. Basic Appl. Sci., 4(6), 1152-1156.

Agbugba, I.K., Okafor, O.E., Etowa, E.B. (2008). Government Intervention in Promoting Agro-Processing in Nigeria. Nig. J. Home Econ. (NigJHEC), 1(1), 68-72.

Amadhila, E.M. (2016). Financing agricultural small- and medium-scale enterprises in Namibia. Western Cape, South Africa: Economic and Management Sciences at Stellenbosch University.

Amadi, D.C.A., Onogwu, G.O., Orisakwe, K.U., Zaku, S.S. (2013). Factors Influencing Mechanized Farming and Farm Size Ownership in Nigeria. J. Agric. Sust., 4(2), 227-234.

Ashburner, J.E., Kienzle, J., FAO, UNIDO (eds.). (2011). Investment in agricultural mechanization in Africa: conclusions and recommendations of a round table meeting of experts ; Hosted by Centre for Agricultural Mechanization and Rural Technologies (CAMARTEC), 3-5 June 2009, Arusha, Tanzania. Rome: Food and Agriculture Organization of the United Nations.

Bishop-Sambrook, C. (2005(. Contribution of farm power to smallholder livelihoods in sub-Saharan Africa. Rome: Food and Agriculture Organisation of the United Nations.
Bowman, M.S., Zilberman, D. (2013). Economic Factors Affecting Diversified Farming Systems. Ecol. Soc., 18(1), 33.

Brink, A., Cant, M., Ligthelm, A. (2003). Problems experienced by small businesses in South Africa. Ballarat: 16th Annual Conference of Small Enterprise Association of Australia and New Zealand, 20.

Campbell, D., Ahmed, I. (2012). The labour market in developing countries. Perspectives on Labour Economics for Development. Washington D.C.: International Labour Organization.

Challa, T.G. (2014). Tractor Service Price Determinants among Smallholder Farmers in Ethiopia. Open Science Repository Agriculture, p. e45011808.

Challa, T.G. (2016). Prospects and Challenges of Agricultural Mechanization in Oromia Regional State - Ethiopia, Policy Perspectives. Am. J. Agric. Forest., 4(5), 118-127.

Daramola, A.G. (1999). The Potential for Animal Traction in South-West Nigeria. Intermediate technology publications, London.

Daum, T., Birner, R. (2017). The neglected governance challenges of agricultural mechanisation in Africa - insights from Ghana. Food Sec., 9(5), 959-979.

Diao, X., Cossar, F., Houssou, N., Kolavalli, S. (2014). Mechanization in Ghana: Emerging demand, and the search for alternative supply models. Food Pol., 48, 168-181.

Economy Watch EW (2010). What do SMEs Need? Economy Watch.

FAO (2005). Contribution of Farm Power to Smallholder Livelihoods in Sub-Saharan Africa. Rome: Food and Agriculture Organisation of the United Nations.

von Hase, F. (2013). Facilitating conservation agriculture in Namibia through understanding farmers' planned behaviour and decision making. Uppsala: Department of Work Science, Business Economics and Environmental Psychology. Swedish University of Agricultural Sciences.

IFC (2013). Working with Smallholders: A Handbook for Firms Building Sustainable Supply Chains. Washington, DC: International Finance Corperation (IFC).

Issa, F.O. (2018). Management of tractor-hiring entrepreneurship by tractor owners and Hiring Facilities Association of Nigeria. J. Agric. Ext., 21(3).

Kamboj, P., Khurana, R., Dixit, A. (2012). Farm machinery services provided by selected cooperative societies. Agric. Eng. Int. CIGR J., 14(4), 123-131.

Maradun, U.M., Sanusi, U.M., Akubuo, C.O. (2013). A Survey of farm tractor management in Zamfara State. Nig. J. Technol., 32(1), 6 .

Maragelo, K.P. (2008). Traditional agriculture and its meaning in the lives of a farming community: the case of Embo. Dissertation, Pietermaritzburg: University of KwazuluNatal. 
Matz, M. (2013). The Time has Come to Turn Hoe to Tractor. Agri-Pulse Communications Inc.

Mijinyawa, Y., Kisaiku, O.O. (2006). Assessment of the Edo state of Nigeria tractor hiring services. Agric. Eng. Int. CIGR J., 8(10), 1-14.

Naushad, K., Muhammad, L., Musawar, S., Akhtar, A., Niaz, M. (2009). The tractor impact in the rural area of District Peshawar. Sarhad J. Agric., 25(3), 509-515.

Norman, M.S. (2012). Effective Small Business Management An Entrepreneurial Approach (Tenth Edition). Upper Saddle River, New Jersey: Pearson Education, Inc., publishing as Prentice Hall.

Parsons, N. (2020). How to Forecast Sales for Your Business the Right Way. LivePlan. Retrieved Sep $21^{\text {st }} 2020$ from: https://www.liveplan.com/blog/the-best-way-to-forecastsales-and-revenue/

Pingali, P. (2007). Agricultural Mechanization: Adoption patterns and economic impact. Rome: Food and Agricultural Organisation of the United Nations.

PropCom (2011). Making Tractor Markets Work for the Poor in Nigeria: A Propcom case study. Abuja Office.

Simalenga, T.E., Belete, A., Mzeleni, N.A., Jongisa, L.L. (1999). Profitability of using animal traction under smallholder farming conditions in Easter Cape, South Africa. University of Fort Hare.

Sims, B., Hilmi, M., Kienzle, J. (2016a). Agricultural mechanization: A key input for sub Saharan African smallholders. Rome: Food and Agriculture Organization of the United Nations.

Sims, B., Hilmi, M., Kienzle, J. (2016b). Consultative meeting on a mechanization strategy: New Models for Sustainable
Agricultural Mechanization in sub-Saharan Africa. Rome: Food and Agriculture Organization of the United Nations.

Sims, B., Kienzle, J. (2006). Farm power and mechanization for small farmers in sub-Saharan Africa. Rome: Food and Agriculture Organization of the United Nations.

Sims, B., Röttger, A., Mkomwa, S. (2011). Hire services by farmers for farmers. Rome: Rural Infrastructure and AgroIndustries Division, Food and Agriculture Organization of the United Nations.

Singha, K.J., Jaman, M.S., Chavali, A. (2012). Tractorization and agricultural development in India. J. Glob. Econ., 8(4), 285-294.

Takele, A., Selassie, Y.G. (2018). Socio-economic analysis of conditions for adoption of tractor hiring services among smallholder farmers, Northwestern Ethiopia. Cogent Food Agric., 4(1), 1-15.

Takeshima, H., Edeh, H.O., Lawal, A.O., Isiaka, M.A. (2015). Characteristics of Private-Sector Tractor Service Provisions: Insights from Nigeria: Private-Sector Tractor Hiring in Nigeria. Dev. Econ., 53(3), 188-217.

Takeshima, H., Pratt, A.N., Diao, X. (2013). Mechanization and Agricultural Technology Evolution. Agricultural Intensification in Sub-Saharan Africa: Typology of Agricultural Mechanization in Nigeria. ASSA annual meeting, San Diego, CA.

The Nations (2015). Tackling the cost of tractor hiring. The Nation Newspaper.

Zhou, Y. (2016). Agricultural Mechanization in West Africa. Retrieved Oct $31^{\text {st }} 2019$ from: http://www.syngentafoundation.org/sites/g/files/zhg576/f/agricultural_mechanization_in_west_africa_-_yuan_zhou.pdf 
